\title{
Social Responsibility: Can it Contribute for Sustainable Welfarism?
}

\author{
Indra P Tiwari \\ Faculty of Humanities and Social Sciences \\ Pokhara University \\ tiwari.hsdc@gmail.com
}

\begin{abstract}
Human beings as natural persons as well as other juristic persons are expected to contribute to the society as part of social responsibility in addition to their defined legal and professional responsibilities with a view to continuously building a better and equally equitable, peaceful and sustainable society. If defined "social responsibility" as the voluntary contribution of the juristic and natural persons, i.e. government, corporations/companies, organizations/ associations, and individual human beings, should the matter of contributing for the betterment of the society through social responsibility be left to the contributor? Contrarily, in a situation of functioning within the stringent laws, rules and regulation of the Government by all juristic and natural persons, should we expect something more than their legal and main responsibilities from them on the name of social responsibilities? Do society, moreover communities and individuals, expect special/additional social responsibilities from all persons, and if so, what sorts of responsibilities are included with what priorities? Similarly, are there different approaches in defining responsibilities of various persons, juristic and natural? If yes, in what situations and what conditions? Debates are going on about the functions and procedures for undertaking social responsibilities as well. This paper in the above context is discussing the objectives and missions, functions, structure(s), processes, the expectations from social responsibilities fulfilled and unfulfilled, and the impacts in the society as expected and not expected, thereby open up the areas for comprehensive and holistic discussion.
\end{abstract}

Keywords: Social responsibility; Legal responsibility; Ethical responsibility; Welfarism

\section{Introduction}

Despite the present day problems of war, crime, terrorism, violence, corruption, cheating, malfeasances and malpractices, selfishness/self-centeredness, which are born out of human mind singly or collectively in response to actions, reactions and counterreactions and have serious impact in the society, people in general want harmony with fellow human beings and other living being as well as the non-living nature, peace, equity and equality, common interest, tranquility, freedom and liberty thereby want to live in a society of welfare system which is constituted by the joint effort of the welfare society and welfare state. Particularly, the collective actions under organizations/associations, agencies and corporations/companies, are sometimes taken in their narrowest possible sense of responsibility, thus create social and environmental mess in their workplace, towards their clients and customers and in the marketplace, for their own workforce, and in the community in which they are affiliated to, unknowingly, neglectfully, or deliberately. In the past there were community and social codes and value systems which used to control and guide people. In this Twenty-

Journal of Development and Social Engineering

Volume 3 | Number 1 | December 2017, 25-37

ISSN 2382-5332 @ School of Development and Social Engineering, Pokhara University 
First Century human beings are largely inspired by their own destiny, closely guided by societal values and norms, utterly controlled by national constitutional and legal provisions (laws, rules and regulations), and widely propelled by globalization and international standards. In many areas these four components (own destiny, societal values and norms, national constitutional and legal provisions, and globalization and international standards) are mismatching if not mutually exclusive though there are State laws, rules, regulations and guidelines, particularly to comply functions correctly and without hampering the society and the living and non-living environment. However, it is almost impossible to put down in writing what should be done and what should not be done by natural and juristic persons, particularly what should be done beyond their legal and professional duties and obligations on behalf of their corporations or organizations. In this situation, it has thus remained a moral obligation of the successful business corporations/companies, public agencies, civil organizations/associations as well as successful individuals willingly or by virtue of their social status in the society to fulfill certain responsibilities towards the society where they live, work, socialize, spiritualize and govern, which are now termed as 'social responsibilities'.

In reality corporate and public organizations on the name of social responsibility (SR) or corporate social responsibility (CSR) perform a variety of activities with whatsoever objectives including highly organized philanthropic organizations to one shot-donation to certain groups of needy people or simply to not so needy people, but as a part of give-away arrangement as well as some people who demand help personally, this three problems $\backslash$; 'deceptive measurement, responsibility erosion and blinkered culture' underline the CSR paradox (Colle, et al., 2014).

Today, thousands of articles and reports have been published under the heading of social responsibility by academia, media, government agencies, corporations, consultancies, civil societies, andinternational organizations in the form of journal articles, conference papers, books, news articles, magazine, reports and other audio and visual media. In addition thousands of articles are written in newspaper everyday about social responsibility. In such a vast literature, it is almost impossible to find out a universally agreed definition of 'social responsibility' and it is not an easy task to define social responsibility and find out the exact meaning of the social responsibility thus it has become largely clear that searching for a common definition is worthless. Pragmatically the meaning of the social responsibility or corporate social responsibility is that what the individual or corporate contributor does as a part of social responsibility. However, for discussing the matter, the meaning of corporate social responsibility is taken as 'actions that appear to further some social good, beyond the interests of the firm and that which is required by law.' (McWilliams et al., 2006). In the meantime two more definitions are presented here for referring in discussion as the defining institutions which have wide coverage and large entities to consider their meaning. First is the European Commission (2001) which defines CRS as 'a concept whereby companies integrate social and environmental concerns in their business operations and in their interaction with their stakeholders on a voluntary basis'. Similarly, the World Business Council for Sustainable Development (WBCSD) (1999) defines CSR as "The continuing commitment by business to behave ethically and contribute economic development while improving the quality of life of the workforce and their families as well as the local community and the society at large'.

For the use in this paper 'social responsibility' is defined as 'the voluntary action/ contribution of the juristic and natural persons, i.e. government, 
corporations/ companies, organizations/ associations, and individual human beings beyond their defined legal and professional responsibilities with a view to continuously build a better and equally equitable, peaceful and sustainable society'.

This paper in the above context is discussing the objectives and missions, functions, structure(s), processes, the expectations from social responsibilities fulfilled and unfulfilled, and the impacts in the society as expected and not expected, thereby open up the areas for comprehensive and holistic discussion by gathering information from the published sources, particularly books and journal articles, web-information on the subject matter. A logical presentation and discussion method is applied for the presentation of matters. Similarly a holistic approach, incorporating all components and their dynamic interrelationships, is applied on the discussion of its future orientation.

\section{A Historical Perspective on Social Responsibility}

Contribution to the society beyond their mandatory duties has been continued in practice since historic period. In the past there were usually no establishments other than the State and principalities as well as recognized or acquired local authorities as lords, feudal and village/community chiefs, particularly no significant existence of big private companies. There were also no government provisions of social safety and social protection. The emperors, kings, princes, lords and community heads were the contributors to the society, basically based on their judgment and mercy, though they had the right to collect tax, which was mainly used to spend for the security of the territory and facilities of the rulers. Their contributions were in the form of cash and kind in cloth and foodstuff.

What was important during those days that the religious establishments were working more for welfare of the general people particularly teaching them on how to read and write, teaching moral values of the contemporary society, and respect on nature and its principles. They also used to organize help during difficult times - natural disaster, accidents, in sorrows and joys. The Hindu temples and ashrams, Buddhist shrines/ monasteries, Christian churches, Jews temples, Islamic mosques, Sikh gurdwaras and the like were well recognized by the authorities and respected, and demanded by the general public. Those were the early efforts of the welfare society. In fact those noble ideas have been principally carried on even today.

Upon growth of population and emergence of the private sector in a more organized way as companies on the one hand and the partial role of the State towards broadbased development, safety and wellbeing of the people, some sort of additional responsibilities towards the people who work for them beyond the given responsibility have been started. In the meantime, those private sector establishments which started earning profit in a substantial amount, the notion of contributing some portion of the profit back to the society emerged in a form of charity.

\section{Modern Principles and Models of Social Responsibility}

Garriga and Mele (2004) have grouped the corporate social responsibility theories into the following four.

i. Instrumental theories: corporation is seen as only an instrument for wealth creation by maximizing share prices (Firedmann, 1970), achieving competitive advantages (Husted and Allen, 2000; Porter and Kramer, 2002), and marketing (McWilliams and Seigel, 2001; Murray and Montanari, 1986; Varadarajan and Menon, 1988) and the social activities are only means to achieve economic results.

ii. Political theories: power of corporation in the society and a responsible use of this power in the political arena by engaging in the political power system, integrating social contracts, and performing as a corporate citizen (Davis, 1973; Altman and Vidaver-Cohen, 2000; 
Wood and Lodgson, 2002).

iii. Integrative theories: corporation is focused on the satisfaction of social demands by managing social issues (Ackerman, 1973; Greening and Gray, 1994), public responsibilities (Preston and Post, 1981), stakeholders (Berman et al., 1999; Orden and Watson, 1999), and social responsiveness (Carol, 1979, 1991; Wood, 1991) thereby keeping clean, transparent and responsible corporation.

iv. Ethical theories: ethical responsibility to the society by recognizing, accepting and responding the norms of the stakeholders (Donald and Preston, 1995), Universal Rights (Donnelly, 1985; Maritain, 1971), the approached to common goods (Mahom and McGowan, 1991) as well as living and working together for the common goods (Kaku, 1997; Yamaji, 1997); and the approach to sustainable development (WBCSD, 2000).

In practice, each corporate social responsibility theory incorporated four dimensions: (i) profit; (ii) political performance; social demands; and (iv) ethical values, which are the reflections of the above four groups of theories (somehow) in this particular order of importance. The strategy is on maximizing these outputs with minimum input and especially keeping higher the satisfaction of social demands and showing high corporate ethical responsibility.

\section{Relationship between Social Responsibilities and Legal and Ethical Responsibilities}

Today, the role of government agencies, corporations, and civil organizations are increasingly concerned to the society and the living, working, socializing, spiritualizing and governance of the people. Cases of misbehaviour and scandals of corporations are being reported everyday which not only adversely impact to the people and society, they are life threatening as well. In many cases the works of the public sector are also not free of such legally, ethically and socially harmful behaviour. Such misbehaviour have been implicated in sustained vulnerability to some group of people, violation of human rights, polluting the environment and society, misinforming and deliberately harming their own people, i.e. customers, clients, beneficiaries, and the general public. Such behaviour or misbehaviour and actions are done to earn maximum profit when things are not noticed by the other stakeholders or simply to sustain the business by the business establishments and to make the programme successful by the government and civil organizations.

Such illegal and antisocial behaviour of many corporate and public organizations have caused demand to legitimize the practices to society at large. To address these concerns, the private sector as well as the public sector has responded with the concept of social responsibility.

However, the question arises that if both the private sector and the public sector including the civil societies, special interest groups and activists' organizations (SIGAOs), or NGOs, operate and conduct their production, distribution and services legally, ethically and professionally, is there a need for legitimizing to society as their activities are concerned to the societal development. The present day stringent laws, rules, regulations and rigorous guidelines clearly spell what are the rights and duties of a private establishment, what each a business establishment can do as part of its licensed or registered permissions. As a juristic person it also must follow all the national laws. On top, each type of activity is also clearly instructed what to avoid and what special attention should be paid so that the environment and local community is not disturbed and harmed, in the meantime they help to strengthen the environmental sustainability and community norms. Since the social responsibility is legally attached in the main professional responsibility, there is no point to work with a separate objective of social responsibility beyond the compliance to the law and regulations. It may even open up the chance to further manipulate the business practice in the name of social responsibility, 
leading to further opaque practice and more damage to the society and the environment.

\section{Forms of Social Responsibility}

Daan/Donation can be considered as the earliest form of contribution as part of social responsibility. There is no element of regularity of this responsibility rather it is event based performance of an individual, corporation, or organization. Though there might be certain basis for donation from the side of the contributor, normally they do not have any procedure, other than making it visible in their record.

Charity on the other hand has been developed under the Christian charity doctrine since the Middle Ages as people in Europe formed groups to alleviate their suffering. Thus, charity working for social responsibility became associated with poverty alleviation. As business took more space in the society, it has turned to philanthropy and diversified its functions to various social activities, particularly education and scholarship, health services, community infrastructure, environment and sanitation, and social events, where such activities are good opportunities to rapport building, noticeable to the general public, and getting substantial credit.

The philanthropic practice has become more prominent in the United States, where the government has less direct involvement to social services like education, healthcare, poverty alleviation and encourages to the sector and the community. As a result, philanthropy has become institutional. The emergence and fast development of multinational corporations (MNCs) has extended this practice substantially as they have to legitimize to the society and sustain.

In the recent decades, some people through corporate enterprises have been able to earn very large amount of money, and a substantial part of it want to spent for the societal progress, particularly in issues concerned to society, like the environment and climate change, poverty, deadly disease, epidemic/endemic and general wellbeing of the people. As a result large philanthropic foundations have been established to transparently operate the endowed fund.

Small enterprises which cannot establish philanthropic foundations yet can contribute and are contributing a lot in infrastructure development at the community level in their workplace, marketplace and community. Such infrastructure development constitutes religious establishments, school, college, university buildings, hospital buildings, community houses, child care centres, ashram for old people, sport courts, parks, rest areas, bus stations, cemetery areas and related, entertainment centres, spiritualizing centres and so on to name the major ones.

Services on major social areas like education, healthandsanitation, environment, child and old care have been the attraction of many private sector establishments. Many of the services are separately provided, targeted to the community and some if in a rather small coverage are included in their own system, means in their workplace with their employees. The list of such services is very long and covers almost all areas of the social requirement. Of course it cannot fulfill all the demands of the society such socially motivated actions are recognizable.

Some other establishments yet contribute through organizational participation. Those which cannot contribute much cash and kind, participate for certain causes particularly to promote quality of life, environment, social norms and values, education, health and sanitary, and governance through awareness creation, advocacy, organization of the people and creating popular support, lobbying thereby things done. Now many companies are doing all these to promote their own business and get established in the society. They need to face the challenges and accept the demand of the society and should follow the contemporary societal value system.

The globalization, development in information and telecommunication, other technological development, demographic 
changes, availability of resources, and the choice of the informed citizen will challenge both enterprises to create socially demanded economic progress and public organizations to achieve quality of life and welfarism rather than concentrating on wealth. In this backdrop, the Governments have already completed the Millennium Development Goals (MDGs) (http://www.un.org/millenniumgoals/) and presently implementing the Sustainable Development Goals (SDGs) (https: / / s ustain abled evelopment. un.org/?menu=1300) to buildmorejustifiable societies in working towards welfare states; the MNCs have launched Enterprise 2020 to build the responsible enterprise of the future (http://www.csreurope.org/ enterprise2020.php). These initiatives have addressed the societal challenges through concerted efforts and collaborative actions of all stakeholders. They have realized that the bigger the establishment, bigger the likely threats to the society if they did not fulfil their legal and professional as well as social responsibilities, also bigger the confrontation with and obstacles from the society.

\section{Agents/Actors of Social Responsibility}

Of course the corporate/company establishments are mainly in the issues concerning social responsibility both in academic writings as well as in news media. There are other concerned natural and juristic persons. They include individuals, corporations/companies, public institutions, civil organizations including the SIGAOs/ NGOs. Some have tried to bring the notion of social responsibility under the notion of the corporate social responsibility. In one sense, it might be correct as the private sector is more unruly and according to Friedman (1970) 'the social responsibility of business is to increase its profit'. In that case there should be only the legal responsibility.

If we see the cases from a close scrutiny, most large corporate enterprises in some points have breached the law or involved in unethical practices to increase their profit, to compete with their rivals and to sustain. In many instances, companies are found evading tax as there are clear provisions of tax and one cannot say that they have done so because of unclear tax provisions. If not clear it is their duty to be clear from the tax offices and pay the full tax. In that case all the generous activities shown towards the social responsibility, which are beyond the mandatory responsibility, are the strategies to maximize the profit and/or legitimize their unethical doings.

In some other cases as the corporate enterprises are owned by shareholders and the operators and employees, including the management team, an individual or the team can misinform the shareholders and do unethical or even illegal actions which increase profit of the enterprise and make happy to the shareholders. Yet in other cases some enterprises constitute of too many shareholders, which do not pay enough attentions which deviates them not only from the volunteer social responsibility, they do not know the trespassing to societal interests.

Not only the corporate establishments and enterprises, but also the public enterprises, civil organizations and even government organizations in the name of exclusively fulfilling social responsibilities cross their compliance. As a consequence, corruption, nepotism, bribery, cheating, substandard works and services are still common in the developing societies. For example according to the World Bank estimation about 25 per cent of Africa's annual GDP is lost to corruption. Similarly, the Transparency International (2010) reveals that corruption raises 10 per cent project cost in developing and transition countries, and the Government officials receive bribes to an estimated 20 to 40 per cent of the total official development assistance. In such a context/environment expectation of an altruistic social activity is an illusion only.

Such actions damage the welfare society and welfare state. They also damage the environment thereby cause hardship to the 
people. It is equally more difficult to remind the social responsibilities of organizations particularly the administrators, managers, officers, and operators in organizations despite the changing value system in the society and regulatory provision of civil declaration of their working procedures at workplace, and declaration of their property as part of transparency, they behave as the representative of the governing body at various levels. Firstly, their fundamental job is geared towards social wellbeing and no one should remind about their responsibilities. In the meantime, there is much more difficulty to change the process and practices of these organizations compared to the corporate enterprises and the private sector. With simple adverse effect in the society or not simply having expected impact of their works and responsibilities, the very existence of organizations and job of the people engaged are not in jeopardy, which largely makes them apathetic towards the need and demand of the society, and they forget their social responsibilities.

\section{Expected Public Responsibility in the Private Corporations / Public Responsibilities of Public/ Civil Organizations}

As presented above each juristic person has its defined legal responsibilities which are guided by the legal provisions. Beyond the legal responsibilities, to achieve its social recognition and social acceptance a juristic person particularly corporations and public organizations as their activities would have impact in the society are expected to fulfilsome common and some specific responsibilities. The most common and highly expected areas of social responsibilities as part of ethics of each organization are considered the following with no particular order of importance though arranged somehow from common and general to more specific ones.

- Not disturbing and damaging the living, working, socializing, spiritualizing and governance environment of the community in the working and service areas of the organization.

- Contributing in developing and maintaining a good living, working, socializing, spiritualizing and governance environment to the community in the working and service areas of the organization.

- Maintaining social harmony, cultural manners, and peace between the organization and the local community.

- Keeping the environment (workplace and neighbourhood) clean, controlling, reducing and eliminating the environmental, social and cultural pollutions.

- Participating and contributing in social and cultural activities to be taken place in the community by recognizing their social and cultural values.

- Participating by the managers, officers and labours in socialization.

- Creating awareness and disseminating information about the business activities and their overall contribution to the society, individually and collectively. Such awareness creation include warning and cautions if required to be taken by the concerned people.

- National development services as demonstration part.

- Community development services.

- Taking lead responsibility to organize one or a few special events of national and/or community concerns and joining hands in similar other events.

\section{Methods of fulfilling the responsibilities}

The responsibilities are generally fulfilled mainly by contributing cash and kinds. To make such contributions less burdensome to the organization as well to make it more transparent now there are provisions of volunteer contributions which are counted as tax substitution.

Similarly, building/contributing to infrastructure development for community places like community house, sport courts, parks, natural resources conservation, landscaping, rest areas, bus-stations etc. are common and such activities are making a high demand. Such contributions will 
help the community in fulfilling the gap in infrastructure provisions which are desperately needed by the community.

Furthermore, managing singly or jointly certain community events that are related to the organization is yet another method of fulfilling the responsibilities. Sponsoring certain events in addition to the events organized by the organization is yet another workable method. It will strengthen the organizational relationship with the community and other establishments, stationed in the locality or working in the same/similar fields.

The functionality in performing the social responsibilities can be single performer, synergy development by jointly working together by two or more organizations, community managed, publicprivate-community participation (PPCP) and contributory role. However, a lone performing functionality may be considered yet as a part of strategy of maximizing the profit by the corporate organization, or legal obligation by the public organization. Synergy development with grouping together the organizations working in the workplacemarketplace-neighbourhood and concerned organization more in a form of publicprivate-community participation could be the best model for working in fulfilling social responsibilities.

\section{Conditions for activating social responsibilities}

The social responsibilities of any private organization/company or public organization as part of contribution as discussed above depend upon the situation of that particular organization. Any additional contribution in the name of ethics and particularly fulfilling social responsibilities varies in situations like booming or crisis as well as the regularity continues in time of booming only of the corporate organization and in time of receiving extra budget by the public organization. The amount of cash and kind as well as participation can be increased during boom situation. There are cases of withdrawal or curtailing financial or material contribution by the United Nations, bilateral donor agencies, and multilateral organizations for many important issues previously agreed upon. In financially difficult situation, regular contributions are suspended or curtailed and event-base contributions are stopped. Common responsibilities like participatory contributions are also curtailed as they are not the obligatory responsibilities.

Now questions arise that are they contributing or can they contribute for the society's most pressing issues of poverty and vulnerability? In answering this question two opposing views are important. First, as this is the non-obligatory responsibility thus one should not expect to contribute in society's most pressing issues like poverty, vulnerability and livelihood development. This view is also supported by the notion that social responsibility is one of the strategies of corporate organizations to enhance their product/profit by getting recognition from the society, increasing their reputation in the society, marketing their product, and minimizing the likely common resistance from the individuals and community that are directly in day-today contact with the organization.

Second, though this is not the obligatory responsibility rather it is ethical responsibility and to exist and sustain the organization the societal obligations are required to be fulfilled. Furthermore, working on the interest in and demand of the society is a newly emerged trend in the corporate sector as well. So far the fluctuating contribution is concerned a fluctuation in the level of contribution either cash, kind, or participation occurs as the public budget also fluctuates according to the situation of the economy of the country, priority of a programme, and the changes in the leadership country.

However, in developing countries the corporate culture is not well cultivated and most juristic persons act to fulfill their legal responsibilities only. Even the developed countries despite the long debate on corporate social responsibility, guidelines 
for standard practices are being developed and it has yet to be confirmed whether such guidelines work as expected. In developing the practices on social responsibilities both corporate and public are to be strengthened and their areas of focus should be streamlined where they can contribute substantially, particularly in areas outside their business interest as well as avoiding the scope for bribery and corruption for politicians and government officials.

\section{Social Responsibility in the Era of Welfare Society and Welfare State}

Despite a long debate and discussion as well as a lot of research and studies, the field of social responsibility concerning both corporate and public organizations is yet to be discussed in depth, research and study and come to a more firm conclusion whether it is a futile matter for research, study and discussion, particularly with a view to practical implication to the society. There are still the following important questions that need to be answered.

- If social responsibility is voluntary and a goodwill expectation, should we expect something more than their legal and main responsibilities from all persons natural or juristic on the name of social responsibilities, particularly in a situation of functioning within the stringent laws, rules and regulation of the Government?

- Do societies, moreover communities and individuals, expect special/additional social responsibilities from all persons?

- Ifyes, what sorts of responsibilities are included with what priorities?

- Who evaluates which should be included and which should not be?

- What are the conditions and situations that social responsibilities should be fulfilled on?

- What are the societal conditions and situations that demand for social responsibilities from various juristic and natural persons?

- What are the bases to include or exclude such persons?

- What happens if terminated prematurely?

- Do we need any procedures for undertaking social responsibility other than common guidelines?

These questions are simple but carry a heavy weight in streamlining the social responsibilities of corporate and public organizations which are not covered by the obligatory legal responsibilities. They also help to distinguish between the business strategies and social responsibilities and in the long-term they strongly protect the interest of the consumers and general public.

In searching for answers to the questions and issues raised above, the social responsibilities have to be seen with the perspective of welfare society and welfare state. With the national constitutional and legal provisions and development policies as well as with the welfarism propaganda of various international conventions particularly the Universal Declaration of Human Rights of the International Convention of Human Rights 1948; the right of everyone to social security including social insurance of the International Convention on Economic, Social and Cultural Rights 1966; and social security of working people under various conventions of the International Labour Organization, the major social welfare provisions particularly education, health, adequate standard of living, and livelihood protection are expected to be provided by the State. In Europe and Japan followed by Australia, New Zealand, Canada, Korea, Taiwan social services like education, healthcare and community development remained as the full responsibilities of the Government as well as social security, social safety nets and social protection remained high through public provisions. Actually, State welfarism trend is moving to this direction in developing countries as well. In this context, a recent US format of welfarism, particularly for education, health, community development, and social safety nets through various modalities of corporate social responsibility should not be the new scope and focus of social responsibility of corporate/private sector and the public organizations should be reoriented. With this 
concept, two models of social responsibility, one specifically for the corporate/private sector (figure 1) and another for the total development actors (figure 2) are presented for the new system of social responsibility.

The first model (see figure 1) outlines the framework for a holistic approach to corporate social responsibility (CSR). The corporate enterprise (which is taken in a wider context and include business community, investors and shareholders) should have a direct social responsibility towards the employees and consumers beyond legal responsibility interfacing workplace, marketplace and community at the backdrop of government, local community/ community-based organizations, civil society organization, and NGOs or SAIGOs thereby achieve higher quality of life without compromising governance, socialization and the environment. In other words their new responsibilities can be set as governance, socialization and the environment in the workplace, marketplace and community. This will also lessen some proportion of bribery given by the business community to the politicians and government officials on the one hand and strengthen the tripartite relation of the corporate/business/ enterprise, employee and consumer environment by developing a habit of working for mutual benefit and cultivating a culture of trust in the overly suspicious business/ enterprise environment.

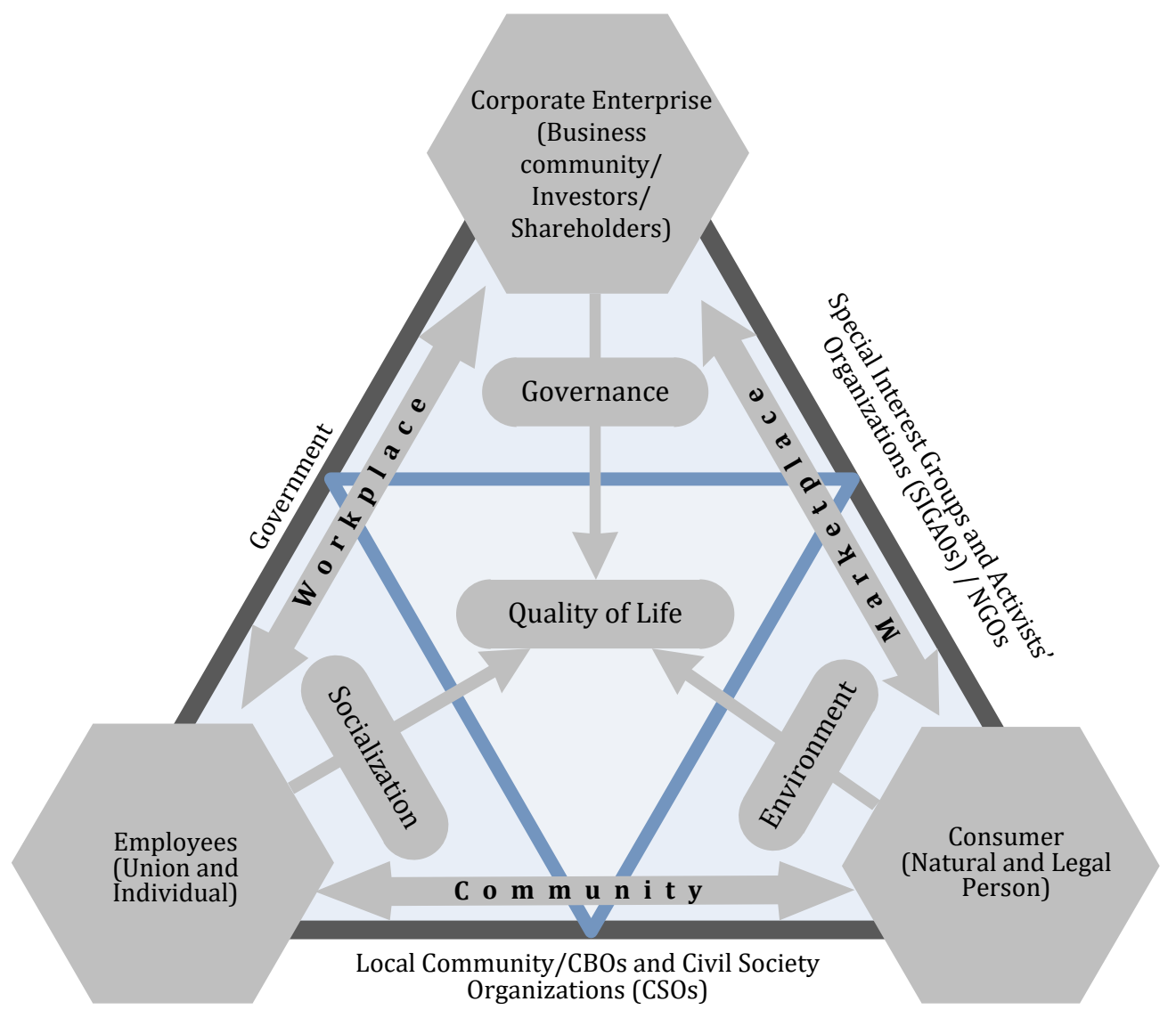

Figure 1: Holistic approach to corporate social responsibility 
The second model (see figure 2), which is a holistic approach to social responsibility (SR), explains that the tripartite actors of development (i) government; (ii) corporate/ private enterprise; and (iii) individuals, communities, CBOs, CSOs, SIAGOs/NGOs have their social responsibilities beyond their legal and professional responsibilities, interfacing workplace, marketplace and community, at the backdrop of laws/rules/ regulations, social welfarism and moral obligations and beyond philanthropy thereby achieve higher quality of life without compromising governance, socialization and the environment. As the common welfare system is obligatory responsibility of the State, the new social responsibility of development actors can be more socialization, spiritualization and governance through organization of and participation in awareness creation, cultural activities, sports, entertainment, and conservation of heritage and environment.

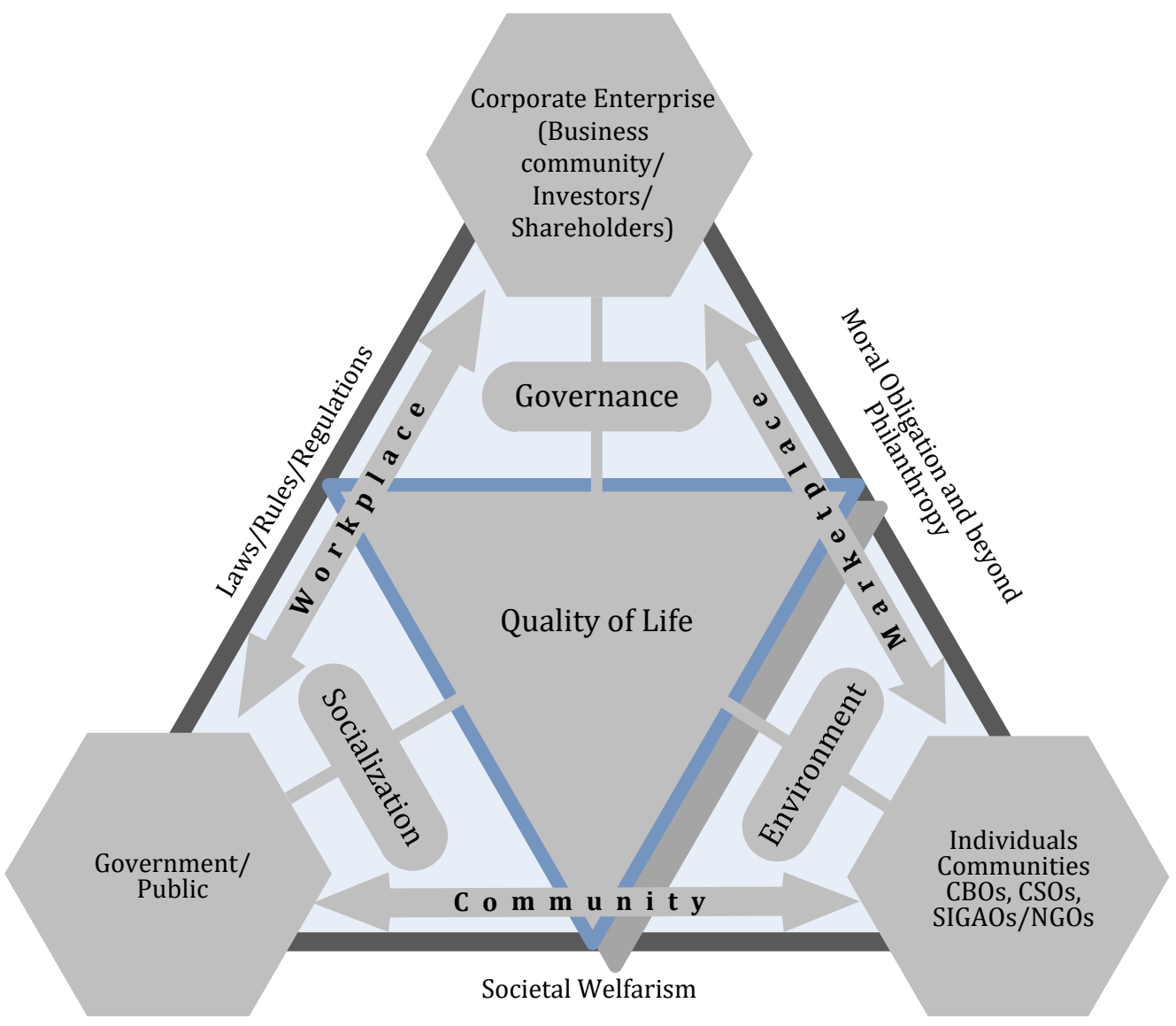

Figure 2: Holistic approach to social responsibility 


\section{Conclusion}

Contribution to society beyond their defined legal and professional responsibilities and as part of social responsibility has remained a practice since long, in different form. There is a continuous debate on this matter and particularly concerning the corporate/ private sector that whether it is a part of the corporate/private sector responsibility with diluted objectives of corporate strategy or as a pure social responsibility it has been established in the corporate environment including the MNCs. It is getting down to the private sector enterprise as a whole. Corporate/private sector whose primary responsibility is not to directly work for the specific well-being of the general public rather to sell products (materials and services) and make profit out of the products, given their difficult objective of profit making to achieve, mainly due to stringent rules and regulations, unpredicted sales of their products, unhealthy competition among themselves and always suspicion among the consumers, general public and government officials, beyond legal and professional responsibilities, some unavoidable social responsibilities are apparent to be accomplished. However, as they are defined differently and perceived differently by different concerned actors, the social responsibilities should be conducted in a way they do not collide with their main business interest and not to disturb the fair and healthy competition. Thus, it should create a true social responsible habit and should cultivate socially responsible culture. What is more important is to designate areas of local and community interest projects for the corporate social responsibility contribution.

\section{Acknowledgements}

The primary version of this paper was presented on the Homecoming Seminar organized by the Graduate School of Social and Environmental Development, National Institute of Development Administration (NIDA), 27 November 2010.

\section{References}

Ackerman, R. W. 1973. How Companies Respond to Social Demands. Harvard University Review 51 (4):88-98.

Altman, B. W. and D. Vidaver-Cohen. 2000. Corporate citizenship in the New Millennium: foundation for an architecture of excellence. Business and Society Review 105 (1):145-169.

Berman, S. L., A. C. Wicks, S. Kotha and T. M. Jones. 1999. Does stakeholder orientation matter? The relationship between stakeholder management models and the firm financial performance. Academy of Management Journal 42 (5):488-509.

Caroll, A. B. 1979. A three-dimensional conceptual model of corporate performance. Academy of Management Review 4 (4):497-505.

Collec, S. de, Henriques, A. and Sarasvathy, S. 2014. The paradox of corporate social responsibility standard. J. Bus Ethics 125:177-191.

Caroll, A. B. 1991. The pyramid of corporate social responsibility: towards the moral management of organizational stakeholders. Business Horizons (July/ August):39-48.

Davis, K. 1973. The case for and against business assumption of social responsibilities. Academy of Management Journal 16 (312-322).

Donaldson, T. and L. E. Preston. 1995. The stakeholder theory of corporation: concepts, evidence, and implications. Academy of Management Review 20 (1):65-91.

Donnelly, J. 1985. The Concept of Human Rights. London: Croom Helm.

European Commission. 2001. Promoting a European Framework for Corporate Social Responsibility. In EC Green Paper.

Friedmann, Milton. 1970. A Friedman Doctrine - The Social Responsibility of Business is to Increase its Profits. In Corporate Social Responsibility: Readings and Cases in a Global Context, edited by A. Crane, Matten, D., Spence, L.J. London: 
Routledge.

Garriga, E. and D. Mele. 2004. Corporate social responsibility theories: mapping the territory. Journal of Business Ethics 53:51-71.

Greening, D. W. and B. Bray. 1994. Testing a model of organizational response to social and political issues. Academy of Management Journal 37:467-498.

Husted, B. W., Allen, D. B. . 2000. Is it ethical to use ethics as strategy? Journal of Business Ethics 27 (1-2):21-32.

Kaku, R. 1997. The path of Kyosei. Harvard Business Review 75 (4):55-62.

Mahon, J. F. and R. A. McGowan. 1991. Searching for the common goods: a process-oriented approach. Business Horizons 34 (4):79-87.

Maritain, J. 1971. The Rights of Man and Natural Law. New York: Gordian Press.

McWilliams, A., Siegel, D.S., Right, P.M. 2006. Corporate social responsibility: strategic implications. Journal of Management Studies 43 (1):1-18.

Murray, K. B. and J. R. Montanari. 1986. Strategic management of the socially responsible firm: integrating management and marketing theory. Academy of Management Review 11 (4):815-828.

Orden, S. and R. Watson. 1999. Corporate performance and stakeholder management: balancing shareholder and customer interests in the U.K. privatized water industry. Academy of Management Journal 42 (5):526-538.

Porter, M. E. and M. R. Kramer. 2002. The competitive advantage of corporate philanthropy. Harvard Business Review 80 (12):56-69.

Preston, L. E. and J. E. Post. 1975. Private Management and Public Policy. The Principle of Public Responsibility. Englewood Cliffs, NJ: Prentice-Hall.

Transparancy International. 2010. Global Corruption Report 2009: Corruption and the Private Sector. Cambridge: Cambridge University Press.

Varadarajan, P. R. and A. Menon. 1988. Cause-related marketing: a coalignment of marketing strategy and corporate philanthropy. Journal of Marketing 52 (3):58-74.

Wood, D. J. . 1991. Corporate social performance revisited. Academy of Management Review 16 (4):691-718.

WBCSD. 2000. Corporate Social Responsibility: Making Good Business Sense. Geneva: World Business Council for Sustainable Development.

Yamaji, K. 1997. A global perspective of ethics in business. Business Ethics Quarterly 7 (3):35-71.

http://www.un.org/millenniumgoals/

https://sustainabledevelopment. un.org/?menu=1300 